\section{«REEDUCAR INVÁLIDOS ES UN PRO- BLEMA CARO». LA REHABILITACIÓN LABORAL Y LA REINSERCIÓN SOCIAL (ARGENTINA, 1915-1960)}

\author{
«REEDUCATING DISABLED PEOPLE IS AN EXPEN- \\ SIVE PROBLEM». WORK REHABILITATION AND \\ SOCIAL REINSERTION (ARGENTINA, 1915-1960) \\ KARINA RAMACCIOTTI • \\ DANIELA TESTA •
}

Karina Inés Ramacciotti es investigadora independiente del CONICET, con sede de trabajo en el Instituto Interdisciplinario de Estudios de Género (FFyL/UBA). Este trabajo forma parte de un proyecto financiado por CONICET (PIP 11420110100060). e-mail: karinaramacciotti@gmail.com

\section{Resumen}

Este artículo examina las ideas, las políticas y las prácticas efectivas que intentaron, con resultados muy dispares, resolver las demandas de rehabilitación laboral y reinserción social en la Argentina, entre 1915 y 1960 . A partir de los relatos oficiales de los tres primeros congresos médicos sobre la problemática del «lisiado» realizados en 1943, 1946 y 1959, publicaciones científicas, debates de normativas y leyes emanadas del Poder Ejecutivo y Legislativo se plantean interrogantes sobre cómo se conformaron las relaciones entre el mundo laboral y las personas con discapacidad y, en particular, cómo se entretejieron las prácticas médicas de rehabilitación y el acceso al trabajo con las discusiones sobre quiénes y cómo se solventarían las medidas de protección a la «invalidez».
Daniela Edelvis Testa es docente en la Universidad de Buenos Aires y en la Universidad Nacional de San Martín. Este trabajo se encuadra en el proyecto doctoral en curso de la Facultad de Ciencias Sociales de la UBA.

e-mail:danitestu@yahoo.com.ar

\section{Abstract}

The aim of this paper is to review the concepts, the policies and the material practices that, with a wide range of results, intended to solve the demands for rehabilitation and social reinsertion in Argentina from 1915 to 1960 . The article analyzes the official accounts in the first three Medical Congresses on the issue of "crippled» people -held in 1943, 1946 and 1959-, scientific papers, regulation and act debate at the Executive and Legislative Powers. From these sources arise different issues about the relationship built between the work sphere and disabled people; with special emphasis on the intertwining of work access and medical practices on rehabilitation with debates on who would afford protection measures for the «disabled», and how. 